Christoph Schröter-Schlaack, Leipzig / Irene Ring, Leipzig (corresponding author) / Thomas Koellner, Bayreuth / Rui Santos, Lisbon / Paula Antunes, Lisbon / Pedro Clemente, Lisbon / Raphaël Mathevet, Montpellier/Stockholm / Maud Borie, Montpellier/Norwich / Małgorzata GrodzińskaJurczak, Krakow

\title{
Intergovernmental fiscal transfers to support local conservation action in Europe
}

\begin{abstract}
Against the background of ongoing biodiversity loss and ecosystem degradation, there is a need for more conservation efforts at all governance levels that also take into account the needs of subnational governments, cities and other local authorities. This paper presents a rationale for including ecological indicators in intergovernmental fiscal transfers that redistribute public revenue from national and regional state governments to decentralised governments. Although recommended for introduction in a number of European countries (such as Germany and Poland), to date only Portugal and to some extent France have implemented fiscal transfers for biodiversity conservation in Europe. In this paper we provide, first, a review of existing and proposed schemes across Europe, classifying them in relation to the stages of a policy cycle. Second, we identify critical design features of ecological fiscal transfers (EFT) in order to develop recommendations for improving existing or introducing new EFT schemes.
\end{abstract}

Keywords: ecological fiscal transfers, policy cycle, biodiversity conservation, Europe, Portugal, France, Germany, Poland

\section{Addressing the costs of local conserva- tion action}

Against the backdrop of an alarming rate of global biodiversity loss and ecosystem degradation (e.g. Butchart et al. 2010), the Convention on Biological Diversity's (CBD) strategic plan for biodiversity 2011-2020 calls for further positive incentives for biodiversity conservation and the mobilisation of financial resources to implement biodiversity targets effectively (CBD 2010). One of the key domains of conservation action is the local level. Hence the strategic plan explicitly acknowledges the fiscal needs of subnational governments, cities and other local authorities in this regard.

Multi-level governance has long been identified as a major issue in improving biodiversity conservation policies (PAAVOLA et al. 2009; RING 2008a). A thorough understanding of administrative governance structures and active involvement by local-level governments are critical factors in the success of conservation policies (BRECHIN et al. 2002; GrodzińSKA-JURCZAK/CENT 2011b; WÄTZOLD et al. 2010; BECKEN/Job 2014).
In Europe, the Natura 2000 network of protected areas (PA) established under the Habitats Directive (EC 2011a) is the centrepiece of nature conservation and biodiversity policy. Its aim is to assure the long-term survival of Europe's most valuable and threatened species and habitats. However, decisions about where PA are to be sited are frequently taken at higher levels of government whereas the costs of withholding such areas from other socially and economically beneficial uses are borne by local governments and communities (see for a literature review on costs and benefits at different governmental levels MAYER/JOB 2014). While there are numerous ways to compensate private land users for such losses (e.g. payments for environmental services (PES) or agri-environment schemes), no financial incentives exist to offset the conservation costs incurred by public stakeholders (RING 2008a). Hence there is an emerging rationale for using ecological fiscal transfers (EFT) to give local governments the financial resources they require to maintain or enhance biodiversity conservation and ecosystem services within PA whose environmental benefits extend beyond municipal boundaries. 
The aim of this paper is twofold. First, it provides a review of existing and proposed schemes across Europe, while classifying them along the stages of a conceptual policy cycle. Second, it identifies critical design features of EFT and develops recommendations for advancing its design and implementation depending on their current stage in the policy cycle.

\section{Ecological fiscal transfers (EFT) in the policy cycle}

Fiscal transfer schemes redistribute public revenue from national and regional state governments to decentralised governments. A major aim of these transfers is to provide lower-tier governments with the revenue needed to cover their expenditure on public goods and services. In Europe intergovernmental fiscal transfers account for up to $46 \%$ of subnational expenditure, while in developing and transition economies they can be as much as $60 \%$ of subnational expenditure (SHAH 2007). Another purpose of such schemes is to compensate decentralised governments for expenditure incurred in providing public goods and services that have spillover benewwfits in areas beyond their boundaries, as with health or education services, for example (OLSON 1969). The bulk of fiscal transfers are distributed as lump-sum or general purpose (unconditional) transfers, i. e. the recipient government is free to decide how to use them and thus retains local autonomy. In many countries, subnational governments' fiscal capacity (own source public revenue) and fiscal need (based on specified indicators such as population or area) determine the transfer amount received, constituting a distributive element known as "fiscal equalisation". In addition, there are specific (earmarked or conditional) transfers that are allocated for the provision of certain public goods and services only.

More recently, scholars have begun to analyse biodiversity and ecosystem services in terms of their contribution to human well-being and to assess the economic costs and benefits associated with business as usual compared to timely environmental action, e.g. in combating climate change or halting biodiversity loss (STERN 2007; TEEB 2010, 2011). In this context, an emerging rationale for EFT is given by the spatially unequal distribution of costs and benefits associated with biodiversity conservation. Biodiversity-related fiscal transfers are a powerful means of reconciling the conservation costs encountered at local level with the benefits of biodiversity conservation at higher levels of governance. EFT are thus seen as an innovative policy instrument for providing incentives to local governments to maintain or increase biodiversity conservation activities which provide ecological benefits to society in general (RING 2008a; RING et al. 2011; TEEB 2011). In the 1990s Brazil became the first country to introduce EFT (ICMS Ecológico) to compensate municipalities for land-use restrictions imposed by PA (MAY et al. 2002; RiNG 2008c). In 2007 Portugal introduced a PA-related indicator to redistribute tax revenues from the national to the local level (SANTOS et al. 2012a). France compensates municipalities lying within the core areas of national parks and marine natural parks (BORIE et al. 2014). In other European countries, EFT have been proposed and, in some cases, modelled (SRU 1996; KöLLNER et al. 2002; RING 2002, 2008b; SCHRÖTER-SCHLAACK et al. 2013).

In this article, we discuss the development of EFT in four European countries, namely Portugal, France, Germany and Poland. We do so by reference to the "policy cycle", a standard concept in political science used to describe the development of a policy item stepwise from initial problem identification and agenda setting through to the evaluation and revision stage (EveretT 2003; HowARD 2005; SKOK 1995). Here we use a conceptualisation described by UNEP (2009) based on HowletT/RAMESH (2003) (see Tab. 1).

In the context of public policy making, an agenda is a list of issues or problems to which government officials attend at given times. Thus, problem identification and agenda setting is a process in which policy initiators (e.g. local, regional state and national policy makers, administrators, scholars, lobbyists or NGO representatives) put forward arguments around specific issues to gain politicians' attention. In the context of EFT, then, it is sensible to target relevant policy initiators, who may differ from country to country. In all four countries analysed, EFT have made it onto the policy agenda.

Policy formulation is a process of generating policy options in response to a specific problem. In this process, policy formulators - both inside and outside government - identify and formalise policy options to prepare the ground for the decision-making stage. For EFT, this includes proposing the type of indicators to be used for 
Tab. 1: Ecological fiscal transfers (EFT) in the policy cycle in four European countries

\begin{tabular}{|c|c|c|}
\hline Stage & Steps in designing and implementing EFT & $\begin{array}{l}\text { Country examples } \\
P T \text { FR DE } P L\end{array}$ \\
\hline $\begin{array}{l}\text { Problem identi- } \\
\text { fication and } \\
\text { agenda setting }\end{array}$ & $\begin{array}{l}\text { - make the case for biodiversity conservation by providing evidence of } \\
\text { losses, ecological and economic impacts } \\
\text { demonstrate the fiscal needs of local authorities in relation to imple- } \\
\text { menting and managing protected areas (PA) } \\
\text { - get consideration of ecological indicators in fiscal transfers onto the } \\
\text { policy agenda }\end{array}$ & $\sqrt{ }$ \\
\hline $\begin{array}{l}\text { Policy } \\
\text { formulation }\end{array}$ & $\begin{array}{l}\text { - develop indicators demonstrating the quantitative and/or monetary } \\
\text { values (benefits) associated with local conservation action } \\
\text { - develop indicators reflecting local governments' conservation costs } \\
\text { - develop indicators to measure the conservation performance of local } \\
\text { governments } \\
\text { - identify entry points to integrate ecological indicators in fiscal transfer } \\
\text { schemes } \\
\text { - formulate alternative policy options, e.g., provide different ecological } \\
\text { indicators and entry points for transfer calculation } \\
\text { - recommend the most suitable option(s) to be adopted }\end{array}$ & $\sqrt{ }(\sqrt{ })(\sqrt{ })$ \\
\hline $\begin{array}{l}\text { Decision } \\
\text { making }\end{array}$ & $\begin{array}{l}\text { - identify potential beneficiaries and cost bearers based on scenario ana- } \\
\text { lysis and EFT modelling } \\
\text { - find majorities for a subset of policy options } \\
\text { - decide on the EFT design option to be implemented }\end{array}$ & $\sqrt{ }$ \\
\hline Implementation & $\begin{array}{l}\text { - integrate the selected ecological indicators into the fiscal transfer system } \\
\text { to deliver expected policy outcomes } \\
\text { - identify beneficiaries and cost bearers in practice } \\
\text { - take account of time lags between implementation and visibility of } \\
\text { policy outcomes }\end{array}$ & $\sqrt{ }$ \\
\hline $\begin{array}{l}\text { Evaluation and } \\
\text { improvement }\end{array}$ & $\begin{array}{l}\text { - determine criteria for policy evaluation based on the purpose of EFT } \\
\text { evaluation and information requirements } \\
\text { - collect information via monitoring } \\
\text { - conduct EFT evaluation } \\
\text { - draw lessons and propose policy improvements for EFT }\end{array}$ & $\sqrt{ }$ \\
\hline
\end{tabular}

Source: authors' own compilation

redistributing tax revenues, the potential addressees to be included in the scheme at relevant governance levels and the eligible recipients of EFT given the various objectives of fiscal transfer schemes.

Decision making can be described as a stage where a decision maker selects a course of action from among a small set of policy options identified at the policy formulation stage in view of policy implementation. Decision making is a highly sensitive matter, as the chosen course of action may potentially create winners and losers; this applies even in cases where no action is taken, i. e. when retaining the status quo. It can also be highly technical due to the complexity of the factors involved in assessing and comparing policy options based on their projected consequences.
Implementation is the stage where a selected policy option is translated into action. Failures in implementation often result in policies performing far below expectation. Compared with other, completely new environmental economic instruments, introducing EFT only involves modifying an existing fiscal transfer scheme. Nevertheless, it can be a huge challenge to obtain reliable comparable data suited to regularly updating conservation indicators at the relevant government levels and thereby giving decentralised governments an ongoing incentive to intensify conservation efforts. Furthermore, there may be a substantial time lag between implementation and clear policy outcomes, as the Portuguese case demonstrates.

Evaluation refers to the effort to monitor how a policy has fared during implementation. Evalu- 
ation results and recommendations are fed back into further rounds of policy making. In Portugal, scholars are collaborating with national conservation authorities and local stakeholders (both municipal and private land users) to evaluate the effects of the recently implemented EFT and to develop recommendations for improvement (SARMENTO 2013; Ring/SANTOS 2013).

These five key stages in the policy cycle are listed in Tab. 1 in order to showcase the experience with EFT in the four European countries selected, namely, Portugal, France, Germany, and Poland. These countries were chosen as they are all European Union member states, and either have EFT already implemented or the introduction of ecological indicators into the fiscal transfer system is debated among policymakers. In the next section, we analyse in more detail existing or proposed EFT schemes for each country.

\section{Review of EFT across Europe}

\section{Portugal - evaluating a recent nationwide EFT scheme}

Portugal is divided into 308 municipalities that form 18 districts on the mainland and two autonomous regions, the Azores and Madeira archipelagos (Instituto Nacional de Estatística 2013). In 2007, Portugal integrated EFT into annual transfers from the national general budget to the municipalities in order to compensate for land-use restrictions imposed by PA and Natura 2000 sites (SANTOS et al. 2012a). EFT were introduced via approval of the revised Local Finances Law (LFL), which sets out the general principles and rules for fiscal transfers from the national government level to the local level (municipalities). Portugal thus became the first European Union (EU) member state to acknowledge Natura 2000 sites and other national PA as indicators for the redistribution of public revenues from central to local governments - a landmark in European biodiversity policy. The newly introduced Article 6 of the LFL, which promotes local sustainability, states that "the financial regime of municipalities shall contribute to the promotion of economic development, environmental protection and social welfare". This general objective is supported by several mechanisms, including positive discrimination in fund allocation for municipalities with land designated as Natura 2000 sites or other national PA.
The ecological criteria contained in the amended law are "total area under protection" and "percentage of municipal land designated as PA" (SANTOS et al. 2012a). These are among the set of indicators used to determine the distribution of the General Municipal Fund (FGM), which makes up $50 \%$ of the Financial Equilibrium Fund (FEF). The FGM is allocated to municipalities as follows: $5 \%$ is distributed equally among all municipalities; $65 \%$ is allocated as a function of population density (weighted in order to benefit less populated municipalities) and of the average number of overnight stays in hotels or on campsites; the remaining $30 \%$ is distributed according to 1) the municipalities' total area and 2) the amount of land designated as conservation area (Natura 2000 sites or any other national PA):

- in municipalities with less than $70 \%$ of their territory under Natura 2000 or other PA, $25 \%$ of FGM is allocated in proportion to area, weighted by elevation levels, and $5 \%$ in proportion to land designated as conservation area;

- in municipalities with more than $70 \%$ of their territory under Natura 2000 or other PA, $20 \%$ of FGM is allocated in proportion to area, weighted by elevation levels, and $10 \%$ in proportion to land designated as conservation area.

The principle adopted for these fiscal transfers is non-earmarking, meaning they are lump-sum transfers: the local government beneficiaries are free to decide upon their use. Intergovernmental fiscal transfers are an important revenue source for Portuguese municipalities, although their relative impact varies significantly. In 2008, the share of fiscal transfers as a proportion of total municipal budget varied from $25 \%$ in Lisboa to $97 \%$ in Barrancos. On average, the share of fiscal transfers as a proportion of total municipal revenues is around $60 \%$, revealing that municipalities depend significantly on national funding. Thus any major changes in the LFL allocation criteria are relevant to municipal development strategies (SANTOS et al. 2012a).

When evaluating the recently implemented EFT scheme, a number of factors need to be taken into account. The 2007 amendments to the LFL relate to various funds and allocation criteria (e.g., changes in the population criterion weighting). This gave rise to several crossover effects that had significant implications for the final alloca- 
tion of transfers to each municipality. In order to assess the financial impacts of the new LFL, real transfers in 2008 and 2009 were compared to estimated transfers for the same years under the old criteria (SANTOS et al. 2012b). This comparison makes it possible to identify which municipalities won or lost under the new law (Fig. 1). In 2008, $43 \%$ of all Portuguese municipalities won with the new LFL, with Vila Nova de Gaia being the one with the highest gain at $2.8 \%$. By contrast, Castro Marim bore the highest loss at $-10.3 \%$. In 2009 , there were slight changes: $45 \%$ of all municipalities won with the new criteria; however, wins and losses were more significant. The maximum gain was $5.3 \%$ for Loures and the major loss $-22.8 \%$ for Óbidos.
Using a sample of just four municipalities with more and four with less than $70 \%$ of municipal area as designated conservation area (Tab. 2), it is possible to verify that, in 2008 , the differences in actual transfers received were not very significant compared to the old LFL criteria; only Vila do Bispo loses $5.9 \%$, while all the other municipalities vary between $-1 \%$ and $1 \%$. Among the municipalities with more than $70 \%$ of designated conservation area, only one wins with the new LFL criteria. This indicates that the introduction of the ecological indicator was not sufficient to counterbalance other crossover effects (e.g., the increase in weighting of the FGM population criterion - see, for example, Lisboa as a winner of the new LFL despite hav-

Fig. 1: Comparison of impacts of transfer allocation based on the new and previous LFL criteria, using the same total amount of transfers, in 2008 (left), and 2009 (right)

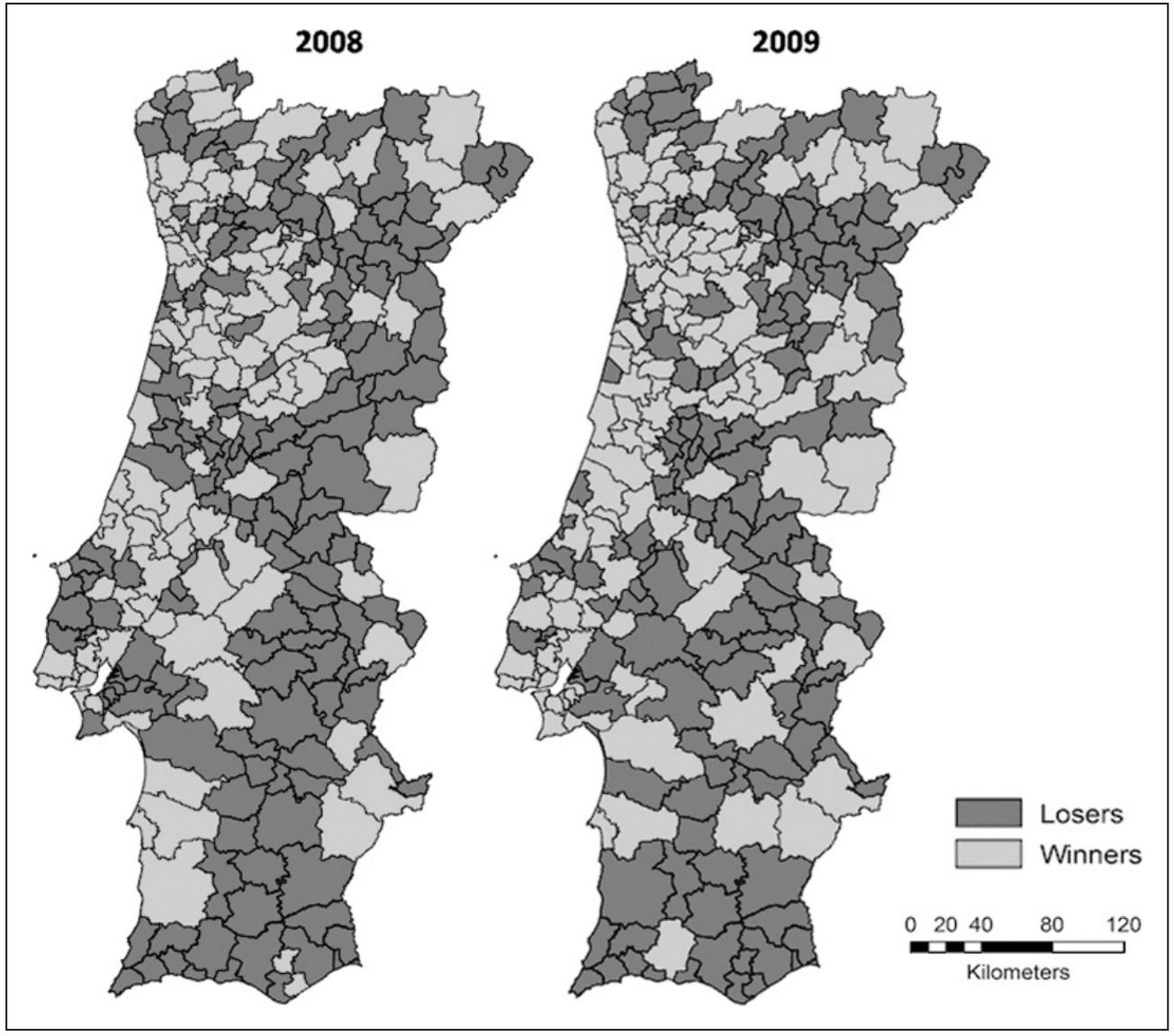

Source: SANTOS et al. 2012b 
Tab. 2: Comparison of impacts of 2008 transfer allocation based on the new and previous LFL criteria

\begin{tabular}{|c|c|c|c|c|c|}
\hline Municipalities & $\begin{array}{c}\text { Share of designated } \\
\text { conservation area } \\
\text { per municipality } \\
(\%)\end{array}$ & $\begin{array}{l}\text { Real transfers } \\
\text { new law } 2008 \\
(€)\end{array}$ & $\begin{array}{l}\text { Applying the old } L F L \\
\text { using the new } L F L \\
\text { national total transfers } \\
(€)\end{array}$ & $\begin{array}{c}\text { Differences } \\
(\%)\end{array}$ & Win/Lose \\
\hline \multicolumn{6}{|c|}{ Municipalities with more than $70 \%$ of designated conservation area } \\
\hline Barrancos & 100 & 3203738 & 3230583 & -0.8 & Loser \\
\hline Vila do Bispo & 97 & 3767189 & 3988693 & -5.9 & Loser \\
\hline Monique & 87 & 6448121 & 6502152 & -0.8 & Loser \\
\hline Porto de Mós & 76 & 6847121 & 6829203 & 0.3 & Winner \\
\hline \multicolumn{6}{|c|}{ Municipalities with less than $70 \%$ of designated conservation area } \\
\hline Mértola & 60 & 10517751 & 10605882 & -0.8 & Loser \\
\hline Aveiro & 49 & 9190900 & 9176537 & 0.2 & Winner \\
\hline Amarante & 27 & 14374890 & 14381184 & -0.04 & Loser \\
\hline Lisboa & 0 & 62579750 & 62403250 & 0.3 & Winner \\
\hline \multicolumn{2}{|c|}{$\begin{array}{l}\text { Total fiscal transfers } \\
\text { (all Portuguese municipalities) }\end{array}$} & 2406532952 & 2406532952 & & \\
\hline
\end{tabular}

Source: SANTOS et al. 2012b

ing $0 \%$ designated conservation area) or provide a higher incentive to those municipalities with a larger proportion of PA. Nevertheless, the detailed analysis by SANTOS et al. (2012a) shows that all municipalities with more than $70 \%$ of their territory under conservation would lose out if the new LFL were to be applied without the ecological criterion.

To analyse in more detail the ecological component introduced with the new LFL, Tab. 3 shows the EFT allocated to a sample of municipalities with more than $70 \%$ of designated conservation areas, their share in proportion to total municipal fiscal transfers, and their share in proportion to total municipal revenues. The results for 2008 and 2009 are quite similar, with variations of $1 \%-2 \%$ (SANTOS et al. 2012b). The share of EFT is fairly relevant for municipalities in this group in 2009, being between $15 \%$ and $28 \%$ in proportion to total fiscal transfers, and between $10 \%$ and $26 \%$ to total municipal revenues. In 2009 the ecological component in Barrancos accounts for $27 \%$ of total fiscal transfers and $26 \%$ of total municipal revenues.

In conclusion, EFT implemented via the new LFL positively discriminate municipalities with a high percentage of designated conservation area. However, the introduction of the ecologic-

Tab. 3: Relevance of EFT for municipal revenues

2008

2009

\begin{tabular}{|c|c|c|c|c|c|c|c|}
\hline & $\begin{array}{c}\text { Share of } \\
\text { designated } \\
\text { conservation } \\
\text { area per } \\
\text { municipality } \\
(\%)\end{array}$ & $\begin{array}{c}\text { Ecological } \\
\text { component } \\
(€)\end{array}$ & $\begin{array}{l}\text { Share of the } \\
\text { ecological } \\
\text { component in } \\
\text { proportion to } \\
\text { total fiscal } \\
\text { transfers } \\
(\%)\end{array}$ & $\begin{array}{l}\text { Share of the } \\
\text { ecological } \\
\text { component in } \\
\text { proportion to } \\
\text { total municipal } \\
\text { revenues } \\
(\%)\end{array}$ & $\begin{array}{l}\text { Ecological } \\
\text { component } \\
(€)\end{array}$ & $\begin{array}{l}\text { Share of the } \\
\text { ecological } \\
\text { component in } \\
\text { proportion to } \\
\text { total fiscal } \\
\text { transfers } \\
(\%)\end{array}$ & $\begin{array}{l}\text { Share of the } \\
\text { ecological } \\
\text { component in } \\
\text { proportion to } \\
\text { total municipal } \\
\text { revenues } \\
(\%)\end{array}$ \\
\hline Barrancos & 100 & 826290 & 26 & 25 & 914063 & 27 & 26 \\
\hline Vila do Bispo & 97 & 855718 & 23 & 12 & 946153 & 25 & 10 \\
\hline Monique & 87 & 1689730 & 26 & 18 & 1877280 & 28 & 19 \\
\hline Porto de Mós & 76 & 982326 & 14 & 11 & 1086111 & 15 & 11 \\
\hline
\end{tabular}

Source: SANTOS et al. 2012b 
al criterion was not sufficient to counterbalance other crossover effects, thereby negating the financial incentive offered to municipalities by the ecological indicator. Due to the significant number of changes introduced, the ecological component is difficult to grasp by the stakeholders concerned and thus poses no greater incentive for conservation (SANTOS et al. 2012a). It is also not clear whether current EFT can compensate for the opportunity costs incurred by municipalities. Finally, this mechanism is too new to enable an evaluation of ecological effectiveness in relation to its direct or indirect impacts on PA management, biodiversity conservation or ecosystem services provision. Nonetheless, it may be an important step in changing the mindset of decision makers.

\section{France-evaluating an existing small-scale system}

In addition to the tax breaks and incentives provided to private land users with land belonging to Natura 2000 sites (e.g., Bulletin Officiel des Impots $2007 \mathrm{a}, \mathrm{b}$ ), the existing French fiscal transfer system (DGF) introduced in 1979 was amended in 2006 to better reflect the costs to municipalities of setting up and managing PA (BORIE et al. 2014). Since 2003, a principle of equality between local authorities has been inserted into the French Constitution which states (article 72.2) that "local authorities have resources that they can allocate as they wish in the conditions determined by the law (...) [and that] the law provides equalisation mechanisms so as to favour equality between local authorities". Hence, the DGF is considered to be an important equalisation mechanism between local authorities in terms of public spending (GUENGANT/JOSSELIN 2006). In 2011 the DGF devoted to municipalities was represented by two main components: (1) a lump-sum allocation representing more than $85 \%$ of the total amount to be distributed and (2) an equalisation allocation. The lumpsum allocation has five main elements:

(1) A base-line amount depending on the number of inhabitants in the municipality of up to $128 €$ per inhabitant.

(2) An amount proportional to the surface area of the municipality and the region where it occurs. Regular areas receive $3.22 €$ per hectare, mountain areas $5.37 €$ per hectare, while overseas territories receive three times the regular amount per hectare.
(3) An amount aimed at compensating municipalities for the loss or reduction of other sources of income (such as the professional tax).

(4) A complementary allocation that seeks to stabilise the amount of the lump-sum allocation.

(5) An "ecological allocation" for municipalities that lie within national parks or natural marine parks, representing the French EFT.

The equalisation allocation is based on the principle of solidarity. It seeks to compensate differences between rural and urban areas and between municipalities with a fiscal capacity lower than the national average. With the adoption of the law on national parks, natural marine parks and regional parks in 2006, a part of the DGF allocation to municipalities depends on whether they are located in the core area of a national park (General Code for Local Authorities, article L2334-7). The scheme is based on the idea of "ecological solidarity" (MATHEVET et al. 2010), meaning that these municipalities are compensated for the opportunity costs of conservation imposed by the land-use restrictions associated with strictly protected areas. The ecological allocation received is based on the following formula:

$$
\begin{aligned}
& E A=\frac{M A_{\text {Park core }} \cdot C o}{M A_{\text {total }}} \cdot P V \\
& E A \quad=\text { Ecological allocation } \\
& M A_{\text {Park core }}= \text { Municipal area in park core area } \\
& M A_{\text {total }}= \text { Total municipal area } \\
& P V \quad= \text { Point Value }=\text { total amount of money to be } \\
& \text { distributed } / \Sigma[\text { municipalities' area in core } \\
& \text { areas } \times \text { coefficient } / \text { total area of eligible } \\
&\text { municipalities }] . \\
&= \text { Coefficient } \\
&=1, \text { if the park area is less than } 5000 \mathrm{~km}^{2} \\
&=2, \text { if the park area is more than } 5000 \mathrm{~km}^{2}
\end{aligned}
$$

In 2010, the total amount of EFT allocated to municipalities was $3.1 \mathrm{~m} €$. In 2011, it was decided that insular cities located in natural marine parks could also benefit from this scheme. Although the French fiscal transfer system takes account of socio-economic inequalities among municipalities, EFT in France remain marginal. In March 2008, it was estimated that there are 36783 municipalities in the French territory, 25000 of which have fewer than 700 inhabitants (BONNARD 2009); only 150 municipalities were eligible for the "ecological allocation". Thus in 2011, although a total of 13.6 bn $€$ were allocated to French municipalities via the DGF, only $0.02 \%$ of this 
amount was allocated on the basis of ecological considerations (i.e. to municipalities that are part of a core area of a national park or marine park).

In the course of implementing the current outcomes of the environment roundtable (Grenelle de l'environnement), participants are exploring whether to extend the French EFT scheme to municipalities with other PA or sensitive areas. The idea is to introduce a "biodiversity criterion" in addition to existing criteria when allocating money to municipalities. In this context, BORIE et al. (2014) have studied various simulations for the Mediterranean region of southern France, a major biodiversity hotspot subject to increasing threats to biodiversity. They examined two redistributive methods for EFT calculation: first, a "per hectare" method, based on the surface area of the PA within municipal boundaries and, second, a "population equivalent" method, where the surface area of PA is converted through weightings into virtual numbers of inhabitants. Results show that, depending on the weights introduced, the population equivalent method can provide a strong incentive to encourage municipalities to designate PA, although larger municipalities with low shares of PA in proportion to their territory would lose more significantly.

The French DGF is a major instrument for mitigating inequalities between municipalities. Since PA provide benefits to society in general, further greening of the fiscal transfer system is consistent with the underlying philosophy of the DGF. Enlarging the current small-scale EFT could thus be used to recognise the efforts made by municipalities at the local level and to contribute to putting the concept of ecological solidarity into practice among different territories (MATHEVET et al. 2010; THOMPSON et al. 2011). By encouraging and rewarding PA designation and management, EFT could enhance society's commitment to conservation and intensify local stewardship. However, there is no direct link between the EFT and environmental activities, as transfers from the Municipal General Fund are not earmarked (BORIE et al. 2014). For averagesized municipalities, overall transfers generally constitute a significant share of the budget so that the EFT portion is rarely visible. For small municipalities with only 100-500 inhabitants, however, the ecological allocation may represent a significant proportion of the budget. Thus EFT in France have highly varied effects on municipalities while their environmental impacts are neither clear nor uniform.

\section{Germany - choosing indicators to model EFT options at regional state and local levels}

Germany is a federal state comprising 16 regional states ("Bundesländer") and 11220 municipalities (Statistisches Bundesamt 2013). The distribution of responsibilities and legislative powers between the federal, regional state and local levels is regulated constitutionally and requires a corresponding system of public revenue distribution. Hence there is one fiscal transfer system established at federal level, targeted at the federal/regional state interface, and 13 fiscal equalisation schemes to the local level in each of the regional states (except for city states Berlin, Hamburg and Bremen). Fiscal transfers have allocative and distributive objectives, the latter being strongly developed in Germany: Fiscal equalisation among the regional states as well as among municipalities requires that disparate fiscal capacities be equalised. Hence public revenue in both systems is distributed mainly by comparing the fiscal capacity of the relevant jurisdiction (including own-source tax income and transfers from shared taxes among governmental levels, such as VAT income) with its fiscal needs. Fiscal needs are standardised on the basis of population figures, taken as an abstract indicator of the public functions to be provided and thus of public spending. The specific needs of German regional states or municipalities are covered by additional indicators (such as population density, pupils or area), some of them being used to weight the number of inhabitants when calculating fiscal needs.

Starting almost two decades ago, proposals to consider ecological indicators have been developed for both the fiscal transfer systems from regional state to local levels (SRU 1996; PERNER/ THÖNE 2007; RING 2002, 2008b) and the federal financial equalisation system (CZYBULKA/LUTTMANN 2005; SCHRÖTER-SCHLAACK et al. 2013). Selecting appropriate indicators to display nature conservation activities and acknowledge conservation costs as fiscal needs is a challenge for various reasons. From a public finance perspective, actual conservation costs need to be assessed to justify the dimension of the changes necessary to the present fiscal transfer system. With the exception of the German city states of Berlin, Bremen and Hamburg, the size of protected areas is clearly linked to the German regional states' net expenditure per capita on nature conservation and environmental protection (Fig. 2). 
Fig. 2: Size of protected areas and net expenditure per capita on nature conservation and environmental protection among Germany's regional states

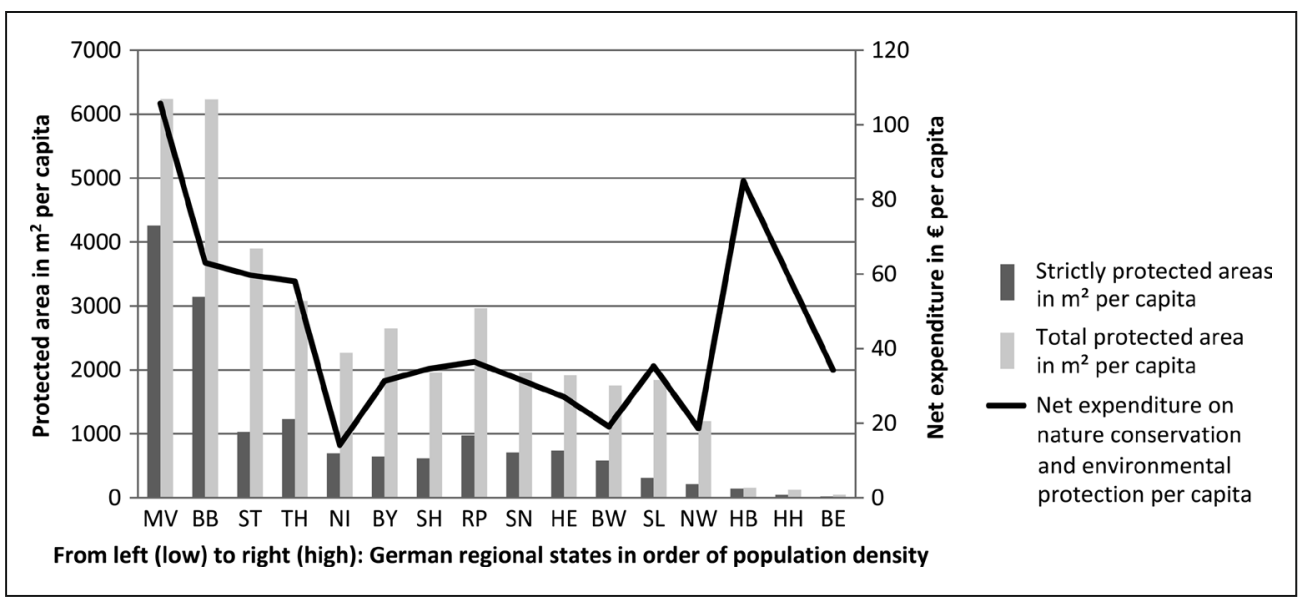

Source: translated from Droste $(2013,45)$. German regional states: BB: Brandenburg, BW: Baden-Württemberg, BY: Bavaria, HE: Hesse, NI: Lower Saxony, MV: Mecklenburg-Western Pomerania, NW: North Rhine-Westphalia, RP: Rhineland-Palatinate, SL: Saarland, SH: Schleswig-Holstein, SN: Saxony, ST: Saxony-Anhalt, TH: Thuringia; German city states: BE: Berlin, HB: Bremen, HH: Hamburg.

From a conservationist's standpoint, indicators should be able to reflect the effectiveness of conservation activities. This may lead to very complex indicators that acknowledge the different goals of nature conservation policies in Germany, namely, to protect certain habitats and landscapes (e.g. via Natura 2000 sites and other national PA), to reduce habitat fragmentation (measured e.g. by mesh-size indicators), pollution and nutrient loads to soils, river bodies and the sea, and to protect endangered species. From an institutional standpoint, indicators have to fulfil legal requirements for fiscal transfers and need to be politically acceptable in order to pass legislation. With regard to the federal level transfer system, for example, it is constitutionally required that indicators must be selected on the basis of abstract features that must not be influenced by the regional state governments (KoRIOTH 1997; MÖCKEL 2013).

Against this background, German EFT proposals for fiscal transfers to the local level focus on quantitative indicators such as size of PA or share of PA as a proportion of total municipal area - some with qualitative weighting factors for different PA categories (RING 2008b). Recent EFT proposals for amending the federal financial equalisation system tested a stepwise approach of combining area-based with qualitative indicators, such as fragmentation indices
(SCHRÖTER-SCHLAACK et al. 2013). In terms of total redistributed transfers, all proposals take a conservative approach by redirecting a comparatively small proportion of fiscal transfers based on ecological criteria.

\section{Poland - getting EFT onto the political agenda}

In Poland, the implementation of the EU Habitat and Birds Directives has caused much controversy among local policymakers and communities. The designation of Natura 2000 sites and the establishment of monitoring rules have primarily followed expert advice commissioned by the Ministry of the Environment, almost excluding local governments from the process (BELL et al. 2008; Boltromiuk 2010; Cent et al. 2007; DuBel 2010). There has been little public participation or consultation with relevant stakeholders from local communities at the implementation stage of Natura 2000, i.e. the development of management plans for each protected site (GRODZIŃSKA-JURCZAK/CENT 2010, 2011b).

The Polish Association of Presidents and Mayors, whose boroughs include Natura 2000 sites, have lodged an official complaint about this. They have expressed discontent about the short timescales given to formulate opinions about preliminary site borders, the use of purely scientific criteria for selecting the PA (margin- 
alising economic and social aspects), and the system of financing Natura 2000 sites. Currently 1300 out of a total of 2479 boroughs host various forms of PA, e.g., national parks, landscape parks or Natura 2000 sites, whereas in 315 boroughs $50 \%$ or more of total land area is protected (Statistical Yearbook of the Republic of Poland 2011). In practice, land-use restrictions imposed by PA significantly decrease the potential usage of these sites, in particular for economic development (BOLTROMIUK/KLODZINSKI 2011).

So far, no financing mechanism has been established for either local authorities or private land owners which would provide compensation for benefits foregone due to land-use restrictions relating to Natura 2000 sites or PA (CENT et al. 2010; GRODZIŃSKA-JURCZAK/CENT 2011a), even though local governments are expected to accomplish various conservation tasks on their land. Distribution of funds to carry out Natura 2000 tasks has been done in a top-down manner, with almost no resources reaching the local level (ChMielewsi 2008). Moreover, according to the Supreme Chamber of Control, fund management appears to be unsatisfactory, and estimates of how much has already been spent on implementing Natura 2000 are much too low, due mainly to the fact that the expenses incurred by a variety of institutions (e.g. local governments, NGOs, national parks and National Fund of Environment Protection and Water Management) have simply not been included (NIK 2008).

Eventually, the majority of borough councils argued against the way the Natura 2000 network was to be implemented over the country (GRODZIŃSKA-JURCZAK et al. 2012). In this situation, a bottom-up initiative of local governments has proposed an EFT scheme for Polish boroughs. The Council of the Rural Boroughs Association, representing municipalities situated in the protected regions, has drafted an ecological fiscal transfer mechanism, called the Ecological Subsidies Act (http://www.gminyrp.pl/). The proposed act envisages financial compensation for boroughs containing areas that are protected and are therefore excluded from economic development. These compensation payments would be lump-sum transfers, i.e. boroughs could spend them freely on any local government need. Compensation would be calculated on the basis of algorithms proposed by the Ministry of Finance. It is assumed that the approval of the Ecological Subsidies Act would result either in extra expenditure or shifting resources within the current national budget. The total national budget expenditure for this initiative is estimated at around $200 \mathrm{~m} €$. So far, the proposed act has been subject to broad consultation with the General Directorate of Environment Protection, members of the Polish parliament, representatives of national and regional governments, lawyers and, in December 2012, was presented to the parliament. It was also taken up by the Polish president but still awaits final approval (http://www.gminyrp.pl/). The EFT initiative of the Rural Boroughs Association was recently backed by the Polish Parliament Club of the Polish People's Party, which supports compensation for boroughs with at least $50 \%$ of their area designated as PA.

\section{Discussion of critical design features of EFT}

Based on experience with the schemes implemented in Portugal and France as well as on the schemes proposed in Germany and Poland this section highlights six critical EFT design features. One key distinction between EFT schemes is the type of costs or benefits to be acknowledged (RING et al. 2011). One type are management costs, i.e. actual government spending on nature conservation. Compensation for opportunity costs, i. e. the tax revenue foregone due to limited economic opportunities in PA, constitutes another cost type. The latter is the principle adopted for the Portuguese EFT scheme, although no actual opportunity costs have been estimated. These costs are also envisaged in Poland. Lastly, transfers could also be justified by the spillover benefits PAs provide. Public expenditure on conservation may be easier to ascertain from official statistics and thus be more transparent. It may also be more uniform across decentralised jurisdictions compared to opportunity costs or spillover benefits. From a theoretical economic point of view, PA are considered to have no or at most very low opportunity costs once land has been granted official, legally binding PA designation, but this is highly contested from the practical perspective of the stakeholders affected. PA opportunity costs or spillover benefits may be a strong argument in political debates, though they create methodological challenges in terms of measurement and, depending on the country in question, the legal constraints on transfers (e. g. MÖCKEL 2013).

Options for the type of indicators used to distribute transfers include quantitative indicators, 
such as surface area of PA or money spent on nature conservation measures, and qualitative indicators, such as PA quality, connectivity of the landscape, management measures carried out, or ecosystem services provided. Quantitative indicators are usually easier to measure and more transparent; however, they may not adequately reflect the conservation effectiveness of the measures. One way to alleviate this problem is to introduce weightings for different PA categories, favouring stricter PA categories with higher land-use restrictions, as is already practised in Brazilian states and has been proposed for Germany (MAY et al. 2002; RING 2008b). Another are direct PA quality indicators to mirror conservation effectiveness, although regular monitoring poses challenges, characteristics that raise the transaction costs of implementing EFT. Quantitative and qualitative indicators can also complement each other to reflect differences in nature conservation activities between transfer recipients (for Germany, see SCHRÖTERSCHLAACK et al. 2013). In general there is a trade-off between the ecological accuracy of indicators and the reduced complexity required for calculating transfers based on available data, as well as restrictions established by constitutional laws. For example, the German constitution requires indicators to be abstract, general and not prone to influence by the recipients of fiscal transfers (e.g., MöcKel 2013). In this respect, the area covered by Natura 2000 sites as a proportion of total area in the eligible jurisdictions is a promising approach at European level. Both Special Areas of Conservation designated under the Habitats Directive and Special Protection Areas designated under the Birds Directive fulfil specific criteria with regard to nature conservation at European level - and are essentially beyond the influence of local and regional policymakers in receipt of EFT. Furthermore, Article 17 of the Habitats Directive requires Member
States to report every six years on progress made with implementing the Directive. Data collected at subnational levels to feed into national reporting could be used to design qualitative indicators based on actual performance of the Natura 2000 sites.

Another distinction is the scale of the scheme, i.e. the number of decentralised governments that can benefit from EFT. This clearly depends on the ecological indicators chosen. In the French transfer system, only those local governments lying within the core areas of national parks or natural marine parks receive EFT. In Portugal, Natura 2000 and other national PA are included, leading to a much higher number of beneficiaries among Portuguese municipalities. In a pilot phase, schemes could operate with fewer indicators and recipients to test and evaluate their effects before scaling them up. Naturally, the impact of mainstreaming biodiversity conservation will increase as more decentralised governments become eligible to receive EFT. Again, Natura 2000 sites would provide an excellent indicator for national EFT schemes in the European Union since they make up a significant proportion of the national territory of EU member states (see Tab. 4).

The origin or type of funds to be allocated represents another important criterion for EFT. EFT designs like the ones proposed in Germany follow a general approach and place ecological indicators side by side with indicators for other public responsibilities, such as number of inhabitants, surface area or topographical criteria (mountainous regions). One could also reserve a fixed amount or share of the total available transfer budget that is then distributed exclusively according to ecological indicators, as in Portugal. This latter approach would reduce the budget available for other criteria. Both approaches will

Tab. 4: Number of and area covered by Natura 2000 sites as a proportion of total area in France, Germany, Poland and Portugal as of 2013

\begin{tabular}{lccccc} 
State & $\begin{array}{c}\text { Total } \\
\text { national area } \\
\left(\mathrm{km}^{2}\right)\end{array}$ & $\begin{array}{c}\text { Natura } 2000 \\
\text { area } \\
\left(\text { total in } \mathrm{km}^{2}\right)\end{array}$ & $\begin{array}{c}\text { Number of } \\
\text { terrestrial sites }\end{array}$ & $\begin{array}{c}\text { Natura 2000 } \\
\text { area } \\
\left.\text { (terrestrial in } \mathrm{km}^{2}\right)\end{array}$ & $\begin{array}{c}\text { Share of terrestrial } \\
\text { Natura 2000 sites as a pro- } \\
\text { portion of total territory }(\%)\end{array}$ \\
\hline France & 632834 & 110700 & 1735 & 68958 & 10.9 \\
Germany & 357168 & 80753 & 5248 & 55244 & 15.5 \\
Poland & 312679 & 68459 & 982 & 61210 & 19.6 \\
Portugal & 92212 & 21628 & 143 & 19217 & 20.8
\end{tabular}

Source: authors' own compilation based on EC 2014 and Eurostat 2014 
always create winners and losers among jurisdictions, as the total budget available for transfers in any specific year is fixed (unless higher tax revenues in years of economic growth make up for the monies allocated through EFT). Only if the budget for EFT comes from sources created additionally to the available funds for intergovernmental transfers (e.g. through additional or higher taxes) can there be no losers when introducing EFT on top of existing transfers. In such a case, tax payers fund the additional costs of the EFT scheme.

The overall amount of financial resources distributed may be a critical issue for the political uptake of EFT proposals, as (additional) budgets are sorely needed for conservation measures and, in particular, for implementing the Natura 2000 network (see KETTUNEN et al. 2014, WWF/IEEP 2009, SRU 2002 for Germany specifically). To date, all the implemented or proposed schemes redistribute only a small fraction of total transfers. Nevertheless, the changes induced by EFT may be substantial for individual municipalities, especially in rural areas, as the Portuguese and French experience suggests. Whether transfers cover actual conservation expenditure in the form of management costs or compensate for opportunity costs is hard to tell for three reasons. First, management and - more importantly - opportunity costs differ across regions. Hence a certain amount of EFT will cover costs in one municipality but will fall short in another, even though both may have the same amount of PA. Second, if the transfer budget does not increase with more PA, the actual size of the transfers will depend on the conservation activities undertaken by other governments eligible for transfers. For example, if new PA are designated in one municipality, it will receive more EFT, but all other municipalities will receive fewer EFT unless growth in overall tax revenues does not make up the difference. Third, if ecological indicators are put side by side with other criteria for distributing transfers, as is proposed in Germany, changes in relative performance of municipalities or regional states in the other criteria will also affect the amount of EFT allocated. This may lead to under- or overcompensation of management and/or opportunity costs. Nevertheless, scenarios calculated for German EFT schemes at both municipal and regional state levels demonstrate that jurisdictions with significant above-average PA as a proportion of total area clearly belong to the winners of potential EFT schemes (RING 2008b; SCHRÖTER-SCHLAACK et al. 2013; Droste 2013).
A final distinction is the type of transfers: Are they earmarked or lump-sum? Earmarked transfers for nature conservation are often favoured in view of their effectiveness for conservation purposes, whereas lump-sum transfers leave local governments free to decide on spending. This design issue can be interlinked with the type of costs to be compensated. If only PA management costs are eligible for EFT then earmarking may seem to be logical. Given the urgent need for financing, for example, the management of Natura 2000 sites, this is certainly the preferable option from a conservationist's standpoint. However, if EFT are introduced to compensate local governments for the opportunity costs of conservation, spending should not be limited to conservation purposes. If there were no landuse restrictions due to nature conservation, local governments would be equally free to decide on how to spend their budget derived from (taxing) alternative land uses. All schemes implemented or proposed do not earmark transfers for conservation, partly due to constitutional rules regarding fiscal transfers.

An overview of how the EFT schemes and proposals presented above could be classified on the basis of the critical design features identified is provided in Tab. 5. Recommendations regarding which option is preferable will depend on the legal and institutional framework of each country, the number of jurisdictions involved and the governmental level at which the EFT scheme is to be implemented, the other instruments for biodiversity conservation and ecosystem service management in place, and the status of fiscal transfers in the policy cycle.

\section{The roads ahead: Recommendations for different stages in the policy cycle}

Portugal is the only European country so far to have introduced ecological indicators on a national scale covering all PA categories and thereby impacting on most municipalities in the country. Due to the very recent implementation of EFT and the many crossover effects caused by changes to other indicators, the effects are not yet fully visible, and so far experiences have been mixed. A crucial task for authorities and scholars is to continue evaluating the scheme and raising local administrators' awareness of the growing importance of the ecological component of the fiscal transfer system. Another avenue is to work towards quality indicators, e. g. by implementing 
Tab. 5: Design features of EFT schemes in Europe

\begin{tabular}{|c|c|c|c|c|c|}
\hline Design feature & Characteristic & $P T$ & $F R$ & $D E$ & $P L$ \\
\hline Status & & Implemented & Implemented & Proposed & Proposed \\
\hline Date & & 2007 & 2007 & Since 1996 & Since 2012 \\
\hline $\begin{array}{l}\text { Number of } \\
\text { jurisdictions }\end{array}$ & & $\begin{array}{c}308 \\
\text { municipalities }\end{array}$ & $\begin{array}{c}36783 \\
\text { municipalities }\end{array}$ & $\begin{array}{c}16 \text { states; } 11220 \\
\text { municipalities }\end{array}$ & $\begin{array}{c}2479 \\
\text { boroughs }\end{array}$ \\
\hline \multirow{3}{*}{$\begin{array}{l}\text { Type of costs } \\
\text { or benefits } \\
\text { acknowledged }\end{array}$} & Management costs & & & $x$ & $\times$ \\
\hline & Opportunity costs & $x$ & $\times$ & & $x$ \\
\hline & Spillover benefits & $x$ & $x$ & $x$ & \\
\hline \multirow{2}{*}{ Indicators } & Quantitative & Size of PA & $\begin{array}{c}\text { Share of PA as a } \\
\text { proportion of total } \\
\text { area of jurisdiction }\end{array}$ & $\begin{array}{l}\text { Share of PA as a } \\
\text { proportion of total } \\
\text { area of jurisdiction }\end{array}$ & $\begin{array}{c}\text { Under } \\
\text { discussion }\end{array}$ \\
\hline & Qualitative & & & $\begin{array}{l}\text { e.g., weighted } \\
\text { PA categories; } \\
\text { fragmentation }\end{array}$ & \\
\hline \multirow[t]{2}{*}{ Scale } & Small & & $\begin{array}{l}\text { Only municipalities } \\
\text { in core areas } \\
\text { of national and } \\
\text { marine parks }\end{array}$ & & \\
\hline & Large & $\begin{array}{l}\text { All municipal- } \\
\text { ities with any } \\
\text { PA category }\end{array}$ & & $\begin{array}{c}\text { All regional states } \\
\text { or municipalities } \\
\text { with any PA category }\end{array}$ & $x$ \\
\hline \multirow[b]{2}{*}{ Funds } & Fixed budget & & & & Under discussion \\
\hline & $\begin{array}{l}\text { Percentage of } \\
\text { total transfers }\end{array}$ & $\begin{array}{c}\text { Along with } \\
\text { other indicators }\end{array}$ & $\begin{array}{c}\text { Along with } \\
\text { other indicators }\end{array}$ & $\begin{array}{c}\text { Along with } \\
\text { other indicators }\end{array}$ & Under discussion \\
\hline \multirow{2}{*}{$\begin{array}{l}\text { EFT resources } \\
\text { transferred }\end{array}$} & Low & $x$ & $x$ & $x$ & $x$ \\
\hline & High & & & & \\
\hline \multirow{2}{*}{$\begin{array}{l}\text { Type of } \\
\text { transfers }\end{array}$} & Lump-sum & $x$ & $x$ & $\times$ & $x$ \\
\hline & Earmarking & & & & \\
\hline
\end{tabular}

Source: authors' own compilation

weightings for different PA categories in order to provide greater incentives for PA involving stricter conservation categories.

Beyond national and marine nature parks, France is considering scaling up its existing limited EFT system to include other types of PA that also impose management costs on local authorities and land-use restrictions on private land users. A promising approach could be to include Natura 2000 sites. Nevertheless, the conditions for a socially and environmentally sound redistribution of fiscal transfers to provide direct incentives for PA designation require further debate. More research is needed to assess the potential positive and adverse effects of EFT in diverse ecological and social contexts. Whatever EFT allocation formula is to be adopted, it should be monitored carefully and decision makers should remain flexible and able to revise
EFT schemes that appear unequal or less effective than initially expected (BORIE et al. 2014).

In Germany the main task is to get EFT into the policy arena. Further design options are to be explored to spur political debate. This includes different or additional ecological indicators, various ways of integrating ecological indicators into the existing transfer schemes as well as evaluating the compatibility of these options with the constitutional rules for fiscal transfers. A window of opportunity for EFT at the federal level is about to emerge with the phasing out of the Solidarity Pact II by 2019. Under this regulation, East German regional states and Berlin receive supplementary federal grants to overcome structural underdevelopment resulting from the partitioning of Germany. The upcoming reform of the current fiscal transfer system from 2020 onwards is already being widely discussed both by fed- 
eral and regional state politicians and by scholars: integrating ecological indicators appears to be an attractive prospect. Environmentally proactive regional states with a high share of PA, such as Mecklenburg-Western Pomerania, are already promoting the idea of EFT ( $M V$-Schlagzeilen 2008). The German Green Party has also included EFT as an avenue to investigate in its action plan for biodiversity conservation (Bündnis 90/Die Grünen 2012). Furthermore, implementing EFT at federal level may pave the way to consider ecological indicators in fiscal transfer schemes from regional state to local level.

In Poland, conflicts around the lack of compensation programmes for lost income due to landuse restrictions in PA cannot be halted or resolved within the next few years while the detailed management plans for all Natura 2000 sites are being developed. However, financial backing is crucial for local governments who incur actual Natura 2000 management costs. Furthermore, compensation for the public (and private) opportunity costs of conservation may foster effective implementation of the conservation network. Without accurate data on boroughs' and individual owners' costs - the latter have never been assessed - the recently proposed Ecological Subsidies Act cannot be calculated precisely. So far, there is neither an agreed EFT concept in Poland nor consensus among those proposing such initiatives. Solving these problems will require close cooperation between all levels of the administration (HogL et al. 2012) and support from political majorities in the parliament. No matter what EFT design is eventually developed, more information is required on how to manage Natura 2000 sites and PA locally. A limited number of such information programmes have been implemented so far, all of which have been successful (KronenBerG/Bergier 2010). Both financial and information-related solutions for Poland should be backed up by tried-and-tested international know-how.

\section{Conclusion}

In view of the fiscal needs resulting from local conservation actions, practitioners and scholars across Europe are discussing the potential benefits of integrating ecological indicators into fiscal transfer schemes. Such EFT could provide subnational governments, cities and other local authorities with the (additional) funds they need for conservation activities. Moreover, by spot- lighting nature conservation as an important public responsibility eligible for fiscal transfers, EFT may also help to mainstream biodiversity conservation in regional state and local development policies. The major drivers of biodiversity loss imposed by local development, such as habitat destruction through urban sprawl, infrastructure development and land-use intensification, could thus be counterbalanced.

We have reviewed the state of EFT schemes in four European countries at different stages in the policy cycle. We have discussed critical design features of EFT schemes in order to distil lessons learned and recommendations for improving EFT. Promising avenues for future EFT design and implementation include transfers based on qualitative indicators, alongside the quantitative PA-based indicators currently in use in Portugal and France. Further challenges lie in addressing the sustained provision of ecosystem services, e.g., based on a quantification of ecosystem services as provided by MAES et al. (2011) for Europe. It will be interesting to observe how this issue develops further in relation to member states' uptake of the EU Biodiversity Strategy, in particular target 2 action 5 on mapping and assessing the state of ecosystems and their services by 2014 and promoting the integration of their values into accounting and reporting systems at EU and national level by 2020 (EC 2011b). Recent research in Portugal has explored the inclusion of ecosystem services in EFT (SANTOS et al. 2012b), and it will be interesting to follow the evolution of this pioneering scheme.

Despite promising options for EFT, fiscal transfers are first and foremost a distributive instrument to level out vertical and horizontal differences in public budgets available to subnational governments. Hence, funding via fiscal transfers typically depends on a number of different criteria, most of them related to economic and social rather than environmental and conservation objectives. Nevertheless, EFT close an obvious gap in the conservation policy mix in many countries by drawing public policymakers' attention to economic incentives for nature conservation.

\section{Acknowledgements}

This work was supported by the EU-FP7 projects SCALES - Securing the Conservation of biodiversity across Administrative Levels and spatial, temporal, and Ecological Scales 
(http://www.scales-project.net, grant no. 226852) and POLICYMIX - Assessing the role of economic instruments in policy mixes for biodiversity conservation and ecosystem services provision (http://policymix.nina.no, grant no. 244065). The authors would like to express their gratitude to the journal's guest editors and an anonymous reviewer for their comments on an earlier draft.

\section{References}

Becken, S. / Job, H. (2014): Protected areas in an era of global-local change. In: Journal of Sustainable Tourism, (22)4, 507-527.

Bell, S. / Marzano, M. / Cent, J. / Kobierska, H. / PodJed, D. / VAndzinskaite, D. / Reinert, H. / Armaitiene, A. / GRODZIŃSKA-JURCZAK, M. / MuRŠIČ, R. (2008): What counts? Volunteers and their organisations in the recording and monitoring of biodiversity. In: Biodiversity and Conservation, (17) 14, 3443-3454.

Boltromuik, A. (2010): Europejska Sieć Ekologiczna Natura 2000 jako nowy element otoczenia polskiej wsi i rolnictwa. Warszawa. (Instytut Rozwoju Wsi i Rolnictwa Polskiej Akademii Nauk).

Boltromuik, A. / Klodzinski, M. (2011): Natura 2000 jako czynnik zrównoważonego rozwoju obszarów wiejskich regionu Zielonych Płuc Polski. Warszawa. (Instytut Rozwoju Wsi i Rolnictwa Pobrlskiej Akademii Nauk).

Bonnard, M. (2009): Les Collectivités Territoriales. La Documentation Française, Paris.

Borie，M. / Mathevet, R. / Letourneau，A. / Ring, I. / ThOMPSON, J./MARTY, P. (2014): Exploring the contribution of fiscal transfers to protected area policy. In: Ecology and Society, (19)1, 9.

Brechin, S.R. / Wilshusen, P. R. / FortwangleR, C. L. / West, P.C. (2002): Beyond the square wheel. Toward a more comprehensive understanding of biodiversity conservation as social and political process. In: Society \& Natural Resources, (15)1, 41-64.

Bulletin Officiel des Impôts (2007a): Taxe foncière sur les propriétés non bâties. Champ d'application. Exonération temporaire. terrains situes dans les zones humides. Paris. (Direction Générale des Impôts. 6 b-2-07 n 113 du 15 octobre 2007).

Bulletin Officiel des Impôts (2007b): Impôt sur le revenu. Revenus fonciers. Imputation sur le revenu global des déficits fonciers afférents aux dépenses inhérentes au maintien et a la protection du patrimoine naturel autres que les intérêts d'emprunt. Paris. (Direction Générale des Impôts 5 d-4-07 n 125 du 3 décembre 2007).

Bündnis 90/Die Grünen (2012): Biodiversität 2020. Das grüne Handlungskonzept zum Schutz der biologischen Vielfalt. Berlin.

Butchart, S.H. M./Walpole, M. / Collen, B. / van Strien, A. / Scharlemann, J. P. W. / Almond, R. E. A. / Baillie, J. E. M. / Bomhard, B. / Brown, C. / Bruno, J. / Carpenter, K. E. / CArr, G. M. / Chanson, J. / Chenery, A. M. / Csirke, J./ Davidson, N. C. / Dentener, F. / Foster, M./ Galli, A. / Galloway, J. N. / Genovesi, P. / Gregory, R. D. / Hockings,
M. / Kapos, V. / LAmarque, J.-F. / LeVerington, F. / Loh, J. / McGeoch, M.A./McRae, L. / Minasyan, A. / Morcillo, M.H. / Oldfield, T. E. E. / Pauly, D. / Quader, S. / RevenGA, C. / SAuer, J. R. / SKOlNiK, B. / SPEAR, D. / StANWEllSmith, D. / Stuart, S. N. / Symes, A. / Tierney, M. / TyrRELL, T. D. / ViÉ, J.-C. / WATSON, R. (2010): Global biodiversity: Indicators of recent declines. In: Science, (328)5982, 1164-1168.

CBD (Convention on Biological Diversity) (2010): Decision adopted by the conference of the parties to the Convention on Biological Diversity at its tenth meeting: X/22. Plan of Action on Subnational Governments, Cities and Other Local Authorities for Biodiversity. Internet: http:// www.cbd.int/doc/decisions/cop-10/cop-10-dec-22-en.doc, 15.11.2013.

CEnT, J. / GrodzińSKA-JurCZAK，M. / NowAK，N. (2010): Ocena efektów małopolskiego programu konsultacji społecznych wokół obszarów Natura 2000. Public consultation programme Natura 2000 sites in Małopolska - effects' evaluation. In: Chrońmy Przyr. Ojcz., (66)4, 251-260.

Cent, J. / Kobierska, H. / Grodzińska-JurczaK, M. / Bell, S. (2007): Who is responsible for Natura 2000 in Poland? A potential role of NGOs in establishing the programme. In: International Journal of Environment and Sustainable Development, (6)4, 422-435.

ChMielewski, T. J. (Ed.) (2008): Nature conservation management: from idea to practical results. ALTER-NET Project. Lublin / Łódź / Helskinki / Aarhus.

Czybulka, D./Luttmann, M. (2005): Die Berücksichtigung von Leistungen der Länder für das Naturerbe im Finanzausgleichssystem des Bundes. In: Natur und Recht, (27)2, 79-86.

Droste, N. (2013): Naturschutz im föderalen System Deutschlands. Eine ökonomische Perspektive auf einen ökologischen Länderfinanzausgleich. Oldenburg/Leipzig. (Masterarbeit, Universität Oldenburg; Helmholtz-Zentrum für Umweltforschung - UFZ, Leipzig).

Dubel, A. (2010): Public participation in consultations about Natura 2000 sites as a part of participatory management process. In: Lewicka, D. (Ed.): Organisation management: competitiveness, social responsibility, human capital. Kraków, 363-364.

EC (European Commission) (2011a): Natura 2000 network. Internet: http://ec.europa.eu/environment/nature/natura2000, 15. 11.2013.

EC (European Commission) (2011b): Our life insurance, our natural capital: an EU biodiversity strategy to 2020. Internet: http://ec.europa.eu/environment/nature/biodiversity/ comm2006/pdf/2020/1_EN_ACT_part1_v7\%5B1\%5D.pdf, 12.5.2014.

EC (European Commission) (2014): Natura 2000: Nature and biodiversity newsletter. January 2014. Internet: http:// ec.europa.eu/environment/nature/info/pubs/docs/nat2000 newsl/nat35_en.pdf, 12.5.2014.

Eurostat (2014): Area - NUTS 3 regions. Internet: http:// appsso.eurostat.ec.europa.eu/nui/submitViewTableAction. do;jsessionid=9ea7d07e30d67667cf49693e4f4fbce38d42 6d451843.e34MbxeSahmMa40LbNiMbxaMchaPe0, 12.5 . 2014. 
Everett, S. (2003): The policy cycle. Democratic process or rational paradigm revisited? In: Australian Journal of Public Administration, (62)2, 65-70.

GrodzińSKa-JurczaK, M./ Cent, J. (2010): Udział społeczny szansą dla realizacji programu Natura $2000 \mathrm{w}$ Polsce. Public participatory approach - a chance for Natura 2000 implementation in Poland. In: Chrońmy Przyr. Ojcz., (66) 5, 341-352.

GrodzińSKA-JuRCZAK, M./ CENT, J. (2011a): Can public participation increase nature conservation effectiveness? In: Innovation - The European Journal of Social Science Research, (24)3, 307-314.

GrodzińSKA-JuRCZAK, M./CENT, J. (2011b): Expansion of nature conservation areas - problems with Natura 2000 implementation in Poland? In: Environmental Management, (47)1, 11-27.

Grodzińska-Jurczak, M. / Bockowski, M. / Cent, J. / PieTRZYK-KASZYNSKA, A. (2012): Problemy społeczno-ekonomiczne przy wyznaczaniu obszarów Natura 2000 w Polsce. Socio-economic problems during Natura 2000 site selection process. In: TEKA Komisji Ochrony i Kształtowania Środowiska Przyrodniczego Oddziału PAN w Lublinie 9, 64-69.

Guengant, A./ Josselin, J.-M. (2006): Réforme constitutionnelle des finances locales: quels sens donner au principe d'égalité? In: Revue d'Économie Régionale \& Urbaine, (5), 667-682.

HowARD, C. (2005) The policy cycle. A model of post-Machiavellian policy making? In: Australian Journal of Public Administration, (64)3, 3-13.

Howlett, M. / Ramesh, M. (2003): Studying public policy. Policy cycles and policy subsystems. Oxford.

Instituto Nacional de Estatística (2013): Statistical yearbook of Portugal 2012. Lisbon.

JermaczeK, A./PAwlaczyK, P. (2004): Natura 2000 narzędzie ochrony przyrody. Planowanie ochrony obszarów Natura 2000. Warszawa.

Kettunen, M. / ToRkler, P. / RAYment, M. (2014): Financing Natura 2000 in 2014-2020. Guidance handbook. Commissioned by the European Commission DG Environment (Jan 2014 draft). Internet: http://ec.europa.eu/environment/ nature/natura2000/financing/docs/handbook.pdf, 12.5.2014.

Köllner, T. / Schelske, O./SEIDL, I. (2002): Integrating biodiversity into intergovernmental fiscal transfers based on cantonal benchmarking. A Swiss case study. In: Basic and Applied Ecology, (3)4, 381-391.

Korioth, S. (1997): Der Finanzausgleich zwischen Bund und Ländern. Tübingen.

Kronenberg, J. / Bergier, T. (2010): Wyzwania zrównoważonego rozwoju w Polsce. Kraków.

Maes, J. / Paracchini, M.L./Zulian, G. (2011): A European assessment of the provision of ecosystem services. Towards an atlas of ecosystem services. Ispra.

Mathevet, R. / Thompson, J. / Delanoë, O. / Cheylan, M. / Gil-Fourrier, C. / Bonnin, M. (2010): La solidarité écologique: un nouveau concept pour la gestion intégrée des parcs nationaux et des territoires. In: Natures Sciences Sociétés, (18)4, 424-433.
May, P. H. / Veiga Neto, F. / Denardin, V. / Loureiro, W. (2002): Using fiscal instruments to encourage conservation: Municipal responses to the 'ecological' value-added tax in Paraná and Minas Gerais, Brazil. In: Pagiola, S./Bishop, J./Landell-Mills, N. (Eds.): Selling Forest Environmental Services. Market-based Mechanisms for Conservation and Development. London, 173-199.

MAYER, M. / JoB, H. (2014): The economics of protected areas - a European perspective. In: Zeitschrift für Wirtschaftsgeographie, (58)2-3, 73-97.

MÖCKEL, S. (2013): Berücksichtigung von Umwelt- und Naturschutzaufgaben bei der Verteilung von Staatsfinanzen zwischen Bund und Ländern. Erfordernisse und Möglichkeiten im Rahmen des Finanzausgleichs, der Bundesauftrags- und bundeseigener Verwaltung oder den Gemeinschaftsaufgaben. In: Zeitschrift für Europäisches Umweltund Planungsrecht, (11)2, 85-94.

MV-Schlagzeilen (2008): Backhaus begrüßt Erklärung des Bundes und der Länder zur biologischen Vielfalt. MVSchlagzeilen - Nachrichten aus Mecklenburg-Vorpommern. Internet: http://www.mv-schlagzeilen.de/backhausbegruesst-erklaerung-des-bundes-und-der-laender-zur-bio logischen-vielfalt/2418/, 15.11.2013.

NIK (Najwyzsza Izba Kontroli) (2008): Informacja o wynikach kontroli wdrażania ochrony na obszarach Natura 2000. Internet: http://www.nik.gov.pl/kontrole/wyniki-kontrolinik/kontrole, 1664.html, 15.11.2013.

OLson, M. (1969): The principle of "Fiscal Equivalence". The division of responsibilities among different levels of government. In: The American Economic Review, (59)2, 479-487.

PaAvola, J. / Gouldson, A. / KluvánKovÁ-OravskÁ, T. (2009): Interplay of actors, scales, frameworks and regimes in the governance of biodiversity. In: Environmental Policy and Governance, (19)3, 148-158.

Perner, A. / ThÖNE, M. (2007): Naturschutz im kommunalen Finanzausgleich - Anreize für eine nachhaltige Flächennutzung. Bonn / Bad Godesberg. (BfN-Skripten Nr. 192).

RING, I. (2002): Ecological public functions and fiscal equalisation at the local level in Germany. In: Ecological Economics, (42)3, 415-427.

RING, I. (2008a): Biodiversity governance. Adjusting local costs and global benefits. In: Sikor, T. (Ed.): Public and private in natural resource governance. A false dichotomy? London, 107-126.

RING, I. (2008b): Compensating municipalities for protected areas. Fiscal transfers for biodiversity conservation in Saxony, Germany. In: GAIA, (17)1, 143-151.

RING, I. (2008c): Integrating local ecological services into intergovernmental fiscal transfers. The case of the ecological ICMS in Brazil. In: Land Use Policy, (25)4, 485-497.

Ring, I. / May, P. H. / Loureiro, W. / SAntos, R. / Antunes, P. / Clemente, P. (2011): Ecological fiscal transfers. In: Ring, I. / Schröter-Schlaack, C. (Eds.): Instrument mixes for biodiversity policies. Leipzig, 98-118. (POLICYMIX Report No. 2/2011, Internet: http://policymix.nina.no).

RING, I. / SCHRÖTER-SCHLAACK, C. (eds.) (2011): Instrument mixes for biodiversity policies. Leipzig. (POLICYMIX Report No. 2/2011, Internet: http://policymix.nina.no). 
Ring, I. / SANTOS, R. (2013): Aligning ecological fiscal transfers in national and state policy mixes. Portugal and Brazil - the research perspective. Trondheim, Norway. (7th Trondheim Conference on Biodiversity, 27-31 May 2013).

Santos, R. / Ring, I. / Antunes, P. / Clemente, P. (2012a): Fiscal transfers for biodiversity conservation. The Portuguese Local Finances Law. In: Land Use Policy, (29)2, 261-273.

Santos, R. / Antunes, P. / Clemente, P. / Ribas, T. (2012b): Assessment of the role of economic instruments in the Portuguese conservation policymix - a national coarse grain analysis. Lisbon. (POLICYMIX Report No. 1/2012, Internet: http://policymix.nina.no).

SARMENTO, P. (2013): Economic and financial incentives in the Portuguese conservation policy. Role of and challenges for ecological fiscal transfers - the policy perspective. Trondheim, Norway. (7th Trondheim Conference on Biodiversity, 27-31 May 2013).

Schröter-SchlaAcK，C./Ring，I./SchulZ-Zunkel，C./ Möckel, S. / KlenKe, R. / Lienhoop, N. / Lenk, T. (2013): Assessment of existing and proposed policy instruments for biodiversity conservation in Germany: the role of ecological fiscal transfers. Leipzig. (POLICYMIX Report No. 1/2013; Internet: http://policymix.nina.no).

SHAH, A. (2007): A practitioner's guide to intergovernmental fiscal transfers. In: Boadway, R./Shah, A. (Eds.): Intergovernmental fiscal transfers. Principles and practices. Washington DC, 1-53.

SkoK, J.E. (1995): Policy issue networks and the public policy cycle. A structural-functional framework for public administration. In: Public Administration Review, (55)4, 325-332.

SRU (Der Rat von Sachverständigen für Umweltfragen) (1996): Konzepte einer dauerhaft-umweltgerechten Nutzung ländlicher Räume. Sondergutachten. Stuttgart.

SRU (Der Rat von Sachverständigen für Umweltfragen) (2002): Für eine Stärkung und Neuorientierung des Natur- schutzes. Sondergutachten - Zusammenfassung und Fazit. Berlin.

Statistical Yearbook of the Republic of Poland (2011). Internet: http://www.stat.gov.pl/gus/5840_2844_ENG_HTML. htm, 15.11.2013.

Statistisches Bundesamt (2013): Statistisches Jahrbuch 2013. Wiesbaden.

Stern, N. (2007): The economics of climate change. The Stern review. Cambridge.

TEEB (The Economics of Ecosystems and Biodiversity) (2010): The economics of ecosystems and biodiversity. Mainstreaming the economics of nature: A synthesis of the approach, conclusions and recommendations of TEEB. Internet: http://www.teebweb.org, 15.11.2013.

TEEB (2011): The economics of ecosystems and biodiversity in national and international policy making. London. (Ed. by P. ten Brink).

Thompson, J. / Mathevet, R. / Delanoë, O. / Gil-Fourrier, C. / Bonnin, M. / Cheylan, M. (2011): Ecological solidarity as a conceptual tool for rethinking ecological and social interdependence in conservation policy for protected areas and their surrounding landscape. In: Comptes Rendus Biologies, (334)5-6, 412-419.

UNEP (2009): Integrated policymaking for sustainable development. A reference manual. Geneva.

WÄtzold, F. / Mewes, M. / VAn APELdoorn, R. / VARJopuRo, R. / Chmielewski, T. J. / VeeneklaAs, F. / Kosola, M.L. (2010): Cost-effectiveness of managing Natura 2000 sites. An exploratory study for Finland, Germany, the Netherlands and Poland. In: Biodiversity and Conservation, (19)7, 2053-2069.

WWF/IEEP (World Wildlife Fund, Institute for European Environmental Policy) (2009): Innovative use of EU funds to finance management measures and activities in Natura 2000 sites. Brussels. 